Volume. 2 Nomor. 2

Periode: Juli - Desember 2018; hal. 10-25

p-ISSN : 2580-1112; e-ISSN : 2655-6669

Copyrighr@2018

Penulis memiliki hak cipta atas artikel ini

Jurnal Ilmiah Keperawatan Orthopedi (JIKO)

journal homepage:

https://ejournal.akperfatmawati.ac.id

\title{
Penerapan Pendidikan Kesehatan Perawatan TB Paru
}

Ariyani Hidayati ${ }^{1}$, Zahri Darni $^{2}$

Akademi Keperawatan Fatmawati, Jakarta

\begin{abstract}
Abstrak
Tuberkulosis Paru (TB paru) adalah penyakit infeksi menular yang disebabkan oleh mycobacterium tuberculosis, sejenis kuman batang aerobik dan tahan asam yang merupakan organisme patogen maupun saprofit. Salah satu tindakan yang dapat dilakukan oleh perawat dalam upaya mengurangi insiden tuberkulosis paru adalah dengan melakukan penerapan pendidikan kesehatan. Pendidikan kesehatan adalah segala upaya yang direncanakan untuk mempengaruhi orang lain sehingga mereka melakukan apa yang diharapkan oleh seorang pendidik. Tujuan dari penelitian ini adalah untuk menggambarkan penerapan pendidikan kesehatan perawatan TB paru. Metode pengumpulan data yang penulis gunakan yaitu wawancara, observasi, pemeriksaan fisik dan studi dokumentasi. Subjek penelitian adalah dua orang pasien TB paru. Instrumen penelitian yang digunakan yaitu format pengkajian keperawatan medikal bedah. Hasil penelitian setelah dilakukan pendidikan kesehatan perawatan TB Paru terhadap kedua pasien tersebut adalah pasien telah dapat menjelaskan kembali pengertian TB Paru, tanda gejala, akibat lanjut, perawatan dengan cara berhenti merokok, minum OAT sesuai jadwal, mengkonsumsi diet TKTP dan melaksanakan etika batuk serta kontrol sesuai dengan jadwal yang telah ditetapkan.
\end{abstract}

Kata Kunci: Pendidikan Kesehatan, Perawatan, Tuberkulosis.

\section{Abstract}

Pulmonary tuberculosis (pulmonary tuberculosis) is a contagious infectious disease caused by mycobacterium tuberculosis, an aerobic and acid resistant germ which is a pathogenic and saprophytic organism. One of the actions that can be taken by nurses in an effort to reduce the incidence of pulmonary tuberculosis is to implement health education. Health education is all efforts planned to influence other people so that they do what is expected by an educator. The purpose of this study was to describe the application of health care for pulmonary TB care. The method of data collection that I use is interviews, observation, physical examination and documentation study. The research subjects were two pulmonary TB patients. The research instrument used was the format of medical surgical nursing assessment. The results of the study after conducting health care for pulmonary $T B$ care for the two patients were that the patients were able to explain again the notion of pulmonary TB,

1,2 e-mail: akfat ykf@yahoo.co.id 
signs of symptoms, follow-up, treatment by quitting smoking, drinking OAT on schedule, consuming TKTP diet and implementing cough ethics and appropriate control with a predetermined schedule.

Keywords: Health Education, Care, Tuberculosis

\section{Pendahuluan}

Tuberkulosis paru atau biasa yang dikenal dengan TB paru adalah penyakit infeksi menular yang disebabkan oleh mycobacterium tuberculosis, suatu basil aerobik tahan asam, yang ditularkan melalui (airbone). Pada hampir semua kasus, infeksi tuberkulosis didapat melalui inhalasi partikel kuman yang cukup kecil (sekitar 1,5 $\mu \mathrm{m}$ ). Droplet dikeluarkan selama batuk, tertawa, atau bersin. Nukleus yang terinfeksi kemudian terhirup oleh individu yang rentan (hospes). Selama infeksi pulmonari dapat terjadi, organisme yang terhirup terlebih dahulu harus melawan mekanisme pertahanan paru (Asih, 2008).

Pada banyak individu yang terinfeksi tuberkulosis adalah asimtomatis. Pada individu lainnya, gejala berkembang secara bertahap sehingga gejala tersebut tidak dikenali sampai penyakit telah masuk dalam tahap lanjut. Bagaimanapun, gejala dapat timbul pada individu yang mengalami immunosupresif dalam beberapa minggu setelah terpajan oleh basil. Manifestasi klinik yang umum termasuk keletihan, penurunan berat badan, letargi, anoreksia (kehilangan nafsu makan) dan demam ringan biasanya terjadi pada siang hari, "berkeringat malam" dan ansietas umum sering tampak. Dispnea, nyeri dada, dan hemoptisis adalah juga temuan yang umum (Asih, 2008).

Penyakit tuberkulosis paru (TB paru) merupakan salah satu masalah yang sampai saat ini masih belum dapat dituntaskan. Menurut laporan World Health Organization (WHO) pada tahun 2012 Indonesia merupakan peringkat kelima dengan jumlah pasien TB paru sebesar 429 ribu orang. Lima negara dengan jumlah terbesar adalah India,
Cina, Afrika Selatan, Nigeria dan Indonesia (WHO, 2012). Menurut Hasil Riset Kesehatan Dasar Nasional pada tahun 2013, prevalensi penduduk Indonesia yang didiagnosis TB paru adalah 0,4 persen. Lima provinsi dengan nilai tertinggi menderita tuberkulosis paru di Indonesia adalah Jawa Barat $(0,7 \%)$, Papua $(0,6 \%)$, DKI Jakarta $(0,6 \%)$, Gorontalo $(0,5 \%)$, Banten $(0,4 \%)$ dan Papua Barat $(0,4 \%)$.

Berdasarkan laporan morbiditas rawat inap RSUP Fatmawati pada tanggal 1 Januari sampai 30 Juni 2018 jumlah pasien yang dirawat dengan kasus pernapasan sebanyak 387 orang dan diantaranya yang terdiagnosa kanker paru sebanyak 32 orang $(8,26 \%)$, efusi pleura sebanyak 21 orang $(5,42 \%)$, pneumonia sebanyak 185 orang $(47,80 \%)$ dan TB paru sebanyak 149 orang $(38,50 \%)$. Meskipun penyakit TB paru tidak mendominasi sebagian besar penyakit pernapasan, namun apabila pasien tidak patuh dalam pengobatan dapat mengakibatkan kegagalan penyembuhan.

Kegagalan penyembuhan ini biasanya terjadi apabila basil pada pasien tersebut resistensi primer terhadap satu atau lebih dari tuberkulosis yang dipakai. Dan dapat menyebabkan komplikasi seperti batuk darah (hemoptisis, hemoptoe), TB laring, pleuritis eksudatif, pneumotoraks, dan abses paru (Danusantosa, 2013). Komplikasi TB paru dapat dicegah dengan adanya pendidikan kesehatan yang diberikan oleh perawat kepada pasien beserta keluarga.

Pendidikan kesehatan adalah proses yang direncanakan dengan sadar untuk menciptakan peluang bagi individu-individu untuk senantiasa belajar memperbaiki kesadaran (literacy) 
serta meningkatkan pengetahuan dan keterampilan (skills) demi kepentingan kesehatannya (Nursalam, 2012).

Pengetahuan tentang penyakit TB Paru merupakan hal yang sangat penting agar tidak menimbulkan peningkatan jumlah kasus TB Paru akibat penularan dari pasien kepada orang lain, sehingga perlunya seseorang mendapatkan informasi tentang TB dan pencegahannya. Perawat dapat memberikan Health Education berupa informasi langsung atau melalui pemberitahuan tertulis berupa poster tentang cara penularan TB dan pencegahannya (Yuliastuti, 2014).

Berdasarkan penelitian yang dilakukan oleh Ummami (2016), di Puskesmas Simo, Boyolali, Jawa Tengah. Dengan judul penelitian mengenai "Pengaruh Pendidikan Kesehatan Tentang Tuberculosis Terhadap Peningkatan Pengetahuan Dan Sikap Penderita Dalam Pencegahan Penularan Tuberculosis" Penelitian ini menggunakan metode eksperimental dengan desain One Test Pre test - Post test Group. Hasil analisis menunjukkan bahwa sebelum dilakukan pendidikan kesehatan terdapat pengaruh pendidikan kesehatan terhadap pengetahuan, dan setelah dilakukan pendidikan kesehatan sebagian pengetahuan pasien menjadi baik. Sikap pasien tentang pencegahan penularan tuberkulosis sebelum dilakukan pendidikan kesehatan tentang tuberkulosis rata-rata netral. Setelah dilakukan pendidikan kesehatan sebagian besar sikap pasien adalah mendukung.

Berdasarkan laporan morbiditas rawat inap RSUP Fatmawati pada tanggal 1 Januari sampai 30 Juni 2018 jumlah pasien yang dirawat dengan kasus pernapasan sebanyak 387 orang dan diantaranya yang terdiagnosa kanker paru sebanyak 32 orang $(8,26 \%)$, efusi pleura sebanyak 21 orang $(5,42 \%)$, pneumonia sebanyak 185 orang $(47,80 \%)$ dan TB paru sebanyak 149 orang $(38,50 \%)$.
Berdasarkan data diatas insiden TB paru di RSUP Fatmawati menduduki posisi ke dua setelah pneumonia, meskipun demikian diketahui bahwa sebagian besar pasien TB paru yang dirawat dikarenakan kegagalan penyembuhan dan dapat menimbulkan akibat yang cukup fatal sehingga penulis ingin membahas bagaimanakah asuhan keperawatan dalam penerapan pendidikan kesehatan perawatan TB paru?

Tujuan umum penelitian ini adalah untuk mendapatkan gambaran asuhan keperawatan dalam penerapan pendidikan kesehatan perawatan TB paru. Tujuan khusus penelitian ini adalah untuk mendapatkan gambaran pengkajian, diagnosa, perencanaan, pelaksanaan, evaluasi keperawatan pada pasien dalam penerapan pendidikan kesehatan perawatan TB Paru di Lantai IV Selatan Instalasi Teratai RSUP Fatmawati.

\section{Metode Penelitian}

Jenis penelitian ini adalah deskriptif dalam bentuk studi kasus untuk menggambarkan penerapan pendidikan kesehatan pada pasien dengan tuberkulosis paru yang dilakukan melalui pendekatan asuhan keperawatan yang meliputi pengkajian, diagnosa keperawatan, perencanaan, pelaksanaan dan evaluasi.

Kriteria Inklusi: kesadaran pasien compos mentis, pasien terdiagnosa tuberkulosis paru dengan mendapatkan terapi OAT. Kriteria Ekslusi: pasien dengan penurunan kesadaran, pasien yang tidak terdiagnosa tuberkulosis paru. Pada kasus ini penulis memfokuskan dalam penerapan pendidikan kesehatan perawatan TB paru pada pasien di Lantai IV Selatan Instalasi Teratai RSUP Fatmawati Jakarta.

Pendidikan Kesehatan menurut Notoajmodjo, pendidikan kesehatan secara umum adalah segala upaya yang direncanakan untuk mempengaruhi orang lain sehingga mereka melakukan apa 
yang diharapkan oleh seorang pendidik. Tuberkulosis Paru adalah penyakit yang disebabkan oleh mycobacterium tuberculosis yang hampir seluruh organ tubuh dapat terserang olehnya, tetapi yang paling banyak adalah paru-paru.

Instrumen penelitian adalah format pengkajian asuhan keperawatan medikal bedah dan metode pengumpulan data adalah wawancara, observasi, studi dokumentasi dan studi literatur

\section{Hasil Penelitian}

Kasus 1, Pasien bernama $\mathrm{Ny} . \mathrm{Cu}$ berusia 39 tahun, pasien berasal dari suku Sunda Bangsa Indonesia, pendidikan terakhir adalah tamat SD, pasien tinggal di alamat Jl. Elima Ujung RT 01/ 04 kelurahan Limo, Kec. Limo, kota Depok. Pengkajian dilakukan pada tanggal 26 Juni 2018 pasien masuk RSUP Fatmawati Jakarta pada tanggal 13 Juni 2018 melalui IGD RSUP Fatmawati Jakarta dengan diagnosa medis TB paru kategori putus obat.

Keluhan utama pasien adalah pasien mengatakan tenggorokan gatal, batuk terus-menerus, terdapat dahak tetapi sering tidak dapat dikeluarkan, dahak berwarna putih kekuningan. Keluhan disertai demam, keringat dingin, penurunan berat badan hingga $27 \mathrm{~kg}$ dalam kurun waktu setahun dari tahun 2017 yaitu $75 \mathrm{~kg}$ hingga berat badan saat ini $48 \mathrm{~kg}$, pasien tidak mengetahui berat badan sebelum masuk RS dan sesak namun sudah sedikit berkurang. pasien mengatakan dirawat kembali di RS karena pasien putus obat sejak Desember 2017 lalu yang seharusnya selesai pada bulan April 2018.

Pasien mengatakan pernah
terdiagnosa TB paru pada bulan September 2017 dan kemudian putus obat pada bulan Desember 2017, pasien juga pernah dirawat di RSUP Fatmawati pada bulan September 2017 dan RS Cipto Mangun Kusumo pada bulan Januari 2018 dengan diagnosa medis TB paru. Pasien mengatakan sudah 5 tahun menderita diabetes melitus karena sering minum teh kemasan. Pasien mengatakan tidak ada penyakit keturunan seperti diabetes dan hipertensi. Pasien mengatakan dari keluarga hanya pasien yang menderita TB paru.

Lingkungan rumah pasien padat penduduk, dengan ventilasi rumah yang sedikit yaitu tidak semua ruangan dirumah pasien terdapat ventilasi, hanya terdapat 2 ventilasi di ruang tamu depan dan 2 di dapur belakang, pasien mengatakan rumah pasien selalu disapu dan dipel tiap hari, pasien mengatakan pekerjaan suami adalah seorang pemulung.

Berat Badan pasien sebelum sakit $75 \mathrm{~kg}$ pada tahun 2017 dan berat badan sekarang $48 \mathrm{~kg}$, pasien tidak mengetahui BB sebelum masuk RS, tinggi badan 153 $\mathrm{cm}$, Lila $18 \mathrm{~cm}$, IMT 20,52 dan tidak ada pembesaran kelenjar getah bening. Konjungtiva pasien anemis, mukosa bibir kering, postur tubuh kurus, pasien mengatakan nafsu makan baik, makan tiga kali sehari, makan habis satu porsi, tidak ada riwayat alergi makanan, pasien terlihat lemas, membran mukosa kering.

Pasien mengatakan sesak, RR 25 $\mathrm{x} / \mathrm{m}$, inpeksi: pergerakan dada simetris, retraksi otot bantu napas (-) palpasi: taktil fremitus normal, perkusi: sonor, auskultasi: suara napas ronchi -/+ wheezing -/- batuk produktif (+), sekret $(+)$, tidak menggunakan otot bantu napas, cuping hidung tidak ada, benjolan atau massa di dada tidak ada, pernapasan teratur, sianosis tidak ada, terpasang oksigen nasal canul 3 liter/menit (lepas pakai).

Sirkulasi Perifer, Kesadaran kompos metis, TD 98/70 mmHg, N 111 $\mathrm{x} /$ menit, irama teratur dan kuat, tidak ada distensi vena jugularis baik kanan kiri, temperatur kulit hangat, pengisian capilary reffil $<3$ detik, tidak terdapat edema. Sirkulasi Jantung, Kecepatan denyut nadi apical 111x/menit, irama teratur, hasil auskultasi diperoleh irama jantung teratur, tidak terdengar bunyi tambahan seperti murmur dan gallop, tidak ada nyeri dada. 
GDS: $189 \mathrm{~m} / \mathrm{dl}$. Pembesaran kelenjar tiroid tidak ada, tidak ditemukan adanya exoptalmus, tremor, diaporesis, napas berbau keton, poliuri, polidipsi, dan poliphagi. Urine pasien berwarna kuning, tidak terdapat distensi kandung kemih, intake: $2500 \mathrm{ml} / 24 \mathrm{jam}$, output: $2250 \mathrm{ml} / 24 \mathrm{jam}$, balance cairan: $+250 \mathrm{ml}$. Terpasang infus sejak tanggal 13 Juni 2018 dengan cairan $\mathrm{NaCl} 0,9 \%$ per 12 jam 20 tetes/menit, tidak ditemukan adanya retensi, urgensi, disuria, nocturia, inkontinensia.

Keadaan kulit pasien sedang, turgor kulit elastis, temperature kulit hangat $\mathrm{S}: 38,8^{\circ} \mathrm{C}$, warna kulit pasien pucat, tidak ditemukan adanya lesi, luka bakar atau dekubitus, kulit teraba lengket. Kondisi kulit pada tempat pemasangan infus baik dan tidak terdapat tanda-tanda infeksi seperti rubor, tumor, dolor, kalor dan fungsiolaesa. Keadaan rambut: tekstur baik dan rambut pasien tampak berminyak dan lengket.

Pasien dan keluarga mengatakan sudah mendapat penjelasan tentang perawatan TB paru saat pasien di rawat di RS Cipto Mangun Kusumo, namun pasien mengharapkan diberikan penjelasan kembali agar tidak terjadi kegagalan pengobatan.

Diagnosa keperawatan. Penulis merumuskan diagnosa yang disusun pada $\mathrm{Ny} . \mathrm{Cu}$ yaitu: ketidakefektifan bersihan jalan napas tidak efektif berhubungan dengan penumpukan sekret, ketidakefektifan pola napas berhubungan dengan penurunan ekspansi paru, resiko ketidakseimbangan cairan dan elektrolit: kurang dari kebutuhan tubuh berhubungan dengan diuresis osmotik, resiko ketidakseimbangan nutrisi: kurang dari kebutuhan tubuh berhubungan dengan peningkatan kebutuhan metabolisme, intoleransi aktivitas berhubungan dengan ketidakseimbangan antara suplai $\mathrm{O}_{2}$ dan kebutuhan, resiko penyebaran infeksi berhubungan dengan pertahanan sekunder tidak adekuat, defisit perawatan diri: personal hygiene berhubungan dengan kelemahan fisik.
Pada perencanaan ini penulis hanya memfokuskan pada diagnosa resiko penyebaran infeksi, dikarenakan pada diagnosa ini mencakup semua tindakan mandiri perawat dalam penerapan pendidikan kesehatan tentang perawatan TB paru pada pasien dan keluarga.

Resiko penyebaran infeksi berhubungan dengan pertahanan sekunder tidak adekuat. Setelah dilakukan tindakan keperawatan 3x24 jam, diharapkan resiko infeksi tidak terjadi. Suhu tubuh dalam batas normal : $36,1-37,5^{\circ} \mathrm{C}$, membran mukosa lembab, sesak tidak ada, batuk tidak ada, pasien dan keluarga jelas tentang perawatan TB, TB MDR tidak terjadi, hasil lab dalam batas normal : leukosit 5.0-10.0 ribu/ul, LED : 0,0-20,0 mm.

Perencanaan : observasi penyebaran infeksi/sistem limfe dan resiko infeksi melalui batuk, bersin dan meludah, monitor suhu tubuh pasien, berikan pendidikan kesehatan etika batuk, berikan pendidikan kesehatan diet TKTP, berikan pendidikan kesehatan perawatan TB, cara meminum OAT dan TB MDR pada pasien, kolaborasi : lanjutkan terapi pemberian OAT, kolaborasi lanjutkan terapi obat:Paracetamol 3x500 gr (pukul 07.00, 12.00, \&18.00 WIB), Ceftriaxone $1 \mathrm{x} 1 \mathrm{gr}$ (pukul 10.00 WIB), Levofloxacin 1x500 gr (pukul 12.00 WIB)

Kasus 2, Pasien bernama Ny. Ch, jenis kelamin perempuan, umur 32 tahun, pekerjaan Ibu rumah tangga, tamat SD, alamat Jl. Jati Padang Rt 12/02 Kel. Jati Padang, Kec. Pasar Minggu, Jakarta Selatan. Pasien masuk RSUP Fatmawati Jakarta pada tanggal 27 Juni 2018 melalui IGD RSUP Fatmawati Jakarta dengan diagnosa medis TB paru, Anemia gravis, hiperglikemia DM, mioma uteri intramural, IUD malposisi. Pasien masuk IGD pada tanggal 27 Juni 2018. Pengkajian dilakukan pada tanggal 29 Juni 2018.

Keluhan utama pasien saat dikaji adalah pasien mengatakan batuk terus 
menerus sehingga pasien merasa lelah, batuk sudah 1 bulan, sekret berwarna hijau. Keluhan disertai demam, keringat dingin pada malam hari, penurunan $\mathrm{BB}$ $10 \mathrm{~kg}$ dalam 1 bulan dengan berat badan awal $54 \mathrm{~kg}$ dan berat sekarang $45 \mathrm{~kg}$. Pasien mengatakan karena ayah pasien yang memiliki riwayat TB paru 8 tahun lalu dengan pengobatan tuntas selama 6 bulan.

Pasien mengatakan ini pertama kalinya menderita penyakit paru, dahulu memiliki riwayat anemia gravis 2 tahun lalu dan sudah 6,5 tahun menderita diabetes melitus. Pasien mengatakan memiliki keturunan penyakit diabetes, dan 8 tahun lalu ayah pasien memiliki riwayat TB paru 8 tahun lalu dengan tuntas pengobatan.

Pasien mengatakan tinggal di pemukiman yang padat penduduk, dengan ventilasi rumah yang hanya terdapat pada ruang tamu yaitu 2 jendela depan dan 2 jendela di bagian kanan dan kiri, namun kaca dirumah jarang dibuka dan minimnya ventilasi, pasien mengatakan rumah pasien selalu dibersihkan disapu dan dipel tiap hari, pasien mengatakan pekerjaan suami adalah seorang pekerja sebagai pegawai swasta. Pasien mengatakan rumah pasien jauh dari jalan raya.

Berat badan pasien sebelum sakit $54 \mathrm{~kg}$ dan berat badan sekarang $45 \mathrm{~kg}$, terjadi penurunan berat badan $10 \mathrm{~kg}$ dalam kurun waktu satu bulan, tinggi badan $156 \mathrm{~cm}$, Lila $22 \mathrm{~cm}$, IMT : 16, 52, konjungtiva pasien anemis, mukosa bibir kering, postur tubuh kurus, pasien mengatakan nafsu makan menurun, mual ada, makan tiga kali sehari, makan habis satu porsi dan harus dipaksa, tidak ada riwayat alergi makanan, pasien terlihat lemas, membran mukosa kering.

RR 17 x/menit, inspeksi: pergerakan dada simetris, retraksi otot bantu napas (-) palpasi: taktil fremitus normal, perkusi: sonor, auskultasi: suara napas ronchi +/- wheezing -/- batuk produktif $(+), \quad$ sekret $(+), \quad$ tidak menggunakan otot bantu napas, cuping hidung tidak ada, benjolan atau massa di dada tidak ada, pernapasan teratur, sianosis tidak ada.

Sirkulasi Perifer, Kesadaran kompos mentis, TD 131/95 mmHg, N $121 \mathrm{x} /$ menit irama teratur dan kuat, tidak ada distensi vena jugularis baik kanan kiri, temperatur kulit hangat, pengisian capilary reffil $<3$ detik, tidak terdapat edema. Sirkulasi Jantung, Kecepatan denyut nadi apical $121 \mathrm{x} / \mathrm{menit}$, irama teratur, hasil auskultasi diperoleh irama jantung teratur, tidak terdengar bunyi tambahan seperti murmur dan gallop, tidak ada nyeri dada.

GDS: $129 \mathrm{mg} / \mathrm{dl}$. Pembesaran kelenjar tiroid tidak ada, tidak ditemukan adanya exoptalmus, tremor, diaporesis, napas berbau keton, poliuri, polidipsi, dan poliphagi. Urine pasien berwarna kuning, tidak terdapat distensi kandung kemih, intake: $3800 \mathrm{ml} / 24$ jam, output: $3600 \mathrm{ml} / 24 \mathrm{jam}$, balance cairan: $+200 \mathrm{ml}$, terpasang infus sejak tanggal 13 Juni 2018 dengan cairan $\mathrm{NaCl} 0,9 \%$ per 8 jam 20 tetes/menit, tidak ditemukan adanya retensi, urgensi, disuria, nocturia, inkontinensia.

Keadaan kulit pasien sedang, turgor kulit elastis, temperatur kulit hangat S: $38,9{ }^{\circ} \mathrm{C}$, warna kulit pasien pucat, tidak ditemukan adanya lesi, luka bakar atau dekubitus, kondisi kulit pada tempat pemasangan infus baik dan tidak terdapat tanda-tanda infeksi seperti rubor, tumor, dolor, calor dan fungsiolaesa. Keadaan rambut: tekstur baik dan rambut pasien tampak bersih.

Pasien dan keluarga mengatakan sudah mendapat penjelasan tentang perawatan TB paru saat atah pasien menjalani pengobatan 8 tahun lalu, namun pasien mengharapkan diberikan penjelasan kembali agar tidak terjadi kegagalan pengobatan.

Setelah penulis menganalisa data, maka penulis merumuskan diagnosa yang disusun pada Ny. Ch yaitu: ketidakefektifan bersihan jalan napas tidak efektif berhubungan dengan penumpukan sekret, resiko 
ketidakseimbangan nutrisi: kurang dari kebutuhan tubuh berhubungan dengan intake tidak adekuat, resiko penyebaran infeksi berhubungan dengan pertahanan sekunder tidak adekuat.

Pada perencanaan ini penulis hanya memfokuskan pada diagnosa resiko penyebaran infeksi, dikarenakan pada diagnosa ini mencakup semua tindakan mandiri perawat dalam penerapan pendidikan kesehatan tentang perawatan TB paru pada pasien dan keluarga.

Resiko penyebaran infeksi berhubungan dengan pertahanan sekunder tidak adekuat, setelah dilakukan tindakan keperawatan 3x24 jam, diharapkan resiko infeksi tidak terjadi. Suhu tubuh dalam batas normal: 36,1$37,5^{\circ} \mathrm{C}$, membran mukosa lembab, sesak tidak ada, batuk tidak ada, pasien dan keluarga paham tentang perawatan TB, TB MDR tidak terjadi, hasil lab dalam batas normal: leukosit 5.0-10.0 ribu/ul, LED: 0,0-20,0 mm.

\section{Perencanaan:}

observasi penyebaran infeksi/sistem limfe dan resiko infeksi melalui batuk, bersin dan meludah, monitor suhu tubuh pasien, berikan pendidikan kesehatan etika batuk, berikan pendidikan kesehatan diet TKTP, berikan pendidikan kesehatan perawatan TB, cara meminum OAT dan TB MDR pada pasien, kolaborasi : lanjutkan terapi pemberian OAT: rifampisin 1x450 mg (pukul 06.00 WIB), isoniazid 1x300 mg (pukul 06.00 WIB), Pirazinamid 1x $1000 \mathrm{mg}$ (pukul 12.00 WIB), etambutol 1x1000 mg (pukul $18.00 \mathrm{WIB}$ ), kolaborasi lanjutkan terapi obat ceftriaxone $2 \times 1$ gr (pukul 10.00, 22.00 WIB)

Pelaksanaan dan evaluasi yang dilakukan pada $\mathrm{Ny}$. $\mathrm{Cu}$ dan $\mathrm{Ny}$. Ch penulis hanya memfokuskan kepada tindakan tentang menerapkan pendidikan kesehatan kepada pasien dan keluarga tentang penyakit dan perawatan TB paru, terutama pada penerapan cara batuk efektif dan etika batuk, pentingnya diit TKTP, Obat Anti Tuberkolosis (OAT), serta akibat lanjut ke TB MDR. Tindakan ini dilakukan pada dua pasien, pada pasien pertama $\mathrm{Ny}$. $\mathrm{Cu}$ selama tiga hari dari tanggal 26 Juni 2018-28 Juni 2018. Kemudian dilakukan pada pasien kedua yaitu Ny. Ch selama tiga hari dari tanggal 29 Juni 2018-1 Juli 2018.

Pelaksanaan dan Evaluasi kasus 1 pada pasien $\mathrm{Ny}$. Cu tanggal 26 Juni 2018 hingga 28 Juni 2018. Pukul 10.00 WIB mengukur TTV pasien, TD: 100/99 mmHg, N: 90x/menit, RR: 23x/menit, S: $38,9^{\circ} \mathrm{C}$; pukul 10.02 WIB menjelaskan cara batuk efektif, pasien mengatakan masih sulit mengeluarkan dahak dan tampak mampu mengikuti arahan perawat; pukul 11.50 WIB menjelaskan diet TKTP, pasien mengatakan bahwa makanan tinggi protein itu penting untuk membantu proses penyembuhan, karena protein membantu penyembuhan bagian paru yang terkena kuman TB dan akan makan putih telur 5-6 butir perhari dan menganti beras putih dengan beras merah. Pasien tampak paham dan mampu mengulangi penjelasan perawat; pukul 15.10 WIB mengevaluasi batuk efektif, dahak pasien dapat keluar dahak berwarna putih, sebanyak $1 / 4$ sendok teh. Pasien mengatakan bersyukur dahak dapat keluar walaupun sedikit, akan mencobanya lagi nanti.

Sebelum melakukan penerapan pendidikan kesehatan, penulis mengevaluasi kembali mengenai diet TKTP dan etika batuk yang sudah dijelaskan sebelumnya, pasien mampu mengingat dan menjelaskan kembali apa yang sudah dijelaskan oleh penulis. Pukul 10.08 WIB mengukur TTV pasien, TD: $110 / 89 \mathrm{mmHg}, \mathrm{N}: 113 \mathrm{x} /$ menit, RR: $24 \mathrm{x} /$ menit, $\mathrm{S}$ : $39^{\circ} \mathrm{C}$; pukul $10.10 \mathrm{WIB}$ mengevaluasi pasien tentang tata cara batuk efektif, pasien mengatakan saat batuk akan menutup mulut dengan tissue saat batuk, dahak pagi ini belum dapat keluar. Tampak belum dapat mengeluarkan dahak, dan pasien tampak sudah betul melakukan cara batuk efektif dan etika batuk; pukul 10.45 WIB menjelaskan tentang TB MDR, pasien 
mengatakan jika pulang kerumah akan patuh minum obat hingga tuntas, pasien tampak memperhatikan dan paham saat diberikan pendidikan kesehatan; pukul 11.20 WIB menjelaskan pentingnya kontrol kesehatan dan minum OAT sesuai jadwal, pasien mengatakan OAT tidak boleh putus jika telat 1 hari makan akan mengulang kembali dari jadwal semula dan tidak akan putus obat lagi, pasien mampu mengulangi penjelasan perawat; pukul 12.10 WIB menjelaskan dan mengevaluasi mengenai pendidikan kesehatan diet TKTP kemarin, pasien mengatakan fungsi protein sebagai zat yang memperbaiki sel yang diserang kuman TB, contoh makanan protein seperti, putih telur, ayam tanpa kulit, kacang, buah dan sayur. Pasien tampak kooperatif saat diberikan pendidikan kesehatan, pasien mampu mengulangi penjelasan perawat tentang diet TKTP; pukul 13.01 WIB menjelaskan pentingnya PMO dirumah, pasien mengatakan PMO bukan hanya mengingatkan pasien untuk minum obat, tetapi juga mengawasi hingga obat tertelan agar tidak kembali kambuh. Pasien tampak dapat mengulangi penjelasan perawat mengenai fungsi PMO; pukul 14.20 WIB mengevaluasi teknik batuk efektif, pasien mengatakan sudah paham cara batuk efektif. Pasien tampak mampu mendemonstrasikan batuk efektif secara benar dengan $2 \mathrm{x}$ napas dalam biasa, $1 \mathrm{x}$ napas dalam kemudian tahan dan batukkan.

Sebelum menerapkan pendidikan kesehatan, penulis mengevaluasi kembali mengenai batuk efektif, pengobatan TB paru, prinsip pengobatan, OAT, penjelasan TB MDR dan tugas seorang PMO, pasien mampu mengingat dan menjelaskan kembali apa yang sudah dijelaskan oleh penulis. Pukul 12.00 WIB mengukur TTV pasien, TD: 111/89 mmHg, N: 89x/ menit, RR: 19x/menit, S: $37,9^{\circ} \mathrm{C}$; pukul 12.10 WIB memberikan penjelasan OAT pada pasien, pasien mengatakan akan rajin kontrol ke Puskesmas jika obat habis dan pasien mampu menyebutkan akibat dari putus OAT; pukul 15.40 WIB menjelaskan kembali pada pasien sebelum pulang tentang perawatan TB paru, diet TKTP, OAT dan PMO dirumah, pasien mengatakan perawatan TB yaitu dengan meminum OAT secara rutin sesuai dengan anjuran dokter pada waktu yang sama, dengan perbedaan waktu maksimal 30 menit hingga 1 jam (60 menit) dari jam biasa atau jam awal minum OAT, pasien mengatakan makanan protein yang dapat dikonsumsi dirumah yaitu: putih telur, ayam tanpa kulit, ikan, daging dan kacang-kacangan, pasien mengatakan fungsi PMO adalah sebagai pengawas minum OAT hingga OAT tertelan. Pasien tampak sudah paham dan mampu mengulangi beberapa penjelasan perawat.

Evaluasi keperawatan pada Tanggal 28 Juni 2018. Subjektif: pasien mengatakan akan rajin kontrol ke Puskesmas jika obat habis, pasien mengatakan perawatan TB yaitu dengan meminum OAT secara rutin sesuai dengan anjuran dokter pada waktu yang sama, dengan perbedaan waktu maksimal 30 menit hingga 1 jam (60 menit) dari jam biasa atau jam awal minum OAT, pasien mengatakan makanan protein yang dapat dikonsumsi dirumah yaitu: putih telur, ayam tanpa kulit, ikan, daging dan kacang-kacangan, pasien mengatakan fungsi PMO adalah sebagai pengawas minum OAT hingga OAT tertelan. Objektif: pasien tampak sudah paham dan mampu mengulangi beberapa penjelasan perawat, TD: $111 / 89 \mathrm{mmHg}$, N: 89x/ menit, RR: 19x/menit, S: 37, $9^{\circ} \mathrm{C}$.

Pelaksanaan dan Evaluasi kasus 2 pada pasien Ny. Ch tanggal 29 Juni 2018 hingga 1 Juli 2018. Pukul 09.45 WIB mengukur TTV pasien, TD: 121/70 mmHg, N: 90x/menit, RR: 18x/menit, S: $36^{\circ} \mathrm{C}$; pukul 10.02 WIB menerapkan pendidikan kesehatan mengenai TB paru, TB MDR, OAT dan batuk efektif, pasien tampak paham dengan penjelasan perawat dan mampu mengulangi penjelasan pendidikan kesehatan 
mengenai pengertian TB paru penyebab, tanda gejala, dan akibat lanjut bila tidak minum obat akan berlanjut dengan TB MDR, pasien dapat mengulangi cara batuk efektif dengan arahan perawat, dahak belum dapat keluar. Pasien mengatakan karena dahulu ayahnya juga pernah menderita TB paru 8 tahun lalu, TB paru adalah infeksi di paru karena kuman TBC, penyebabnya bisa karena nutrisi yang kurang, lingkungan yang kurang pencahayaan dan terpapar penderita TB paru lainya seperti terkena batuk, pasien mengatakan masih sulit mengeluarkan dahak; pukul 12.40 WIB memberikan pendidikan kesehatan diet TKTP, pasien mengatakan bahwa makanan tinggi protein itu penting untuk membantu penyembuhan bagian paru yang terkena kuman TB atau sel yang dirusak kuman $\mathrm{TB}$, pasien mampu menyebutkan makanan apa saja yang mengandung tinggi protein: putih telur 56 butir perhari ayam tanpa kulitnya, daging tanpa lemaknya, dan karena pasien memiliki DM beberapa makanan karbohidrat dapat diganti dengan beras merah, kentang dan mengurangi memakan buah manis. Pasien tampak paham dan mampu mengulangi penjelasan perawat dengan jelas.

$\begin{array}{llr}\quad \text { Pada } & \begin{array}{l}\text { tanggal 30 Juni } 2018 \\ \text { Sebelum } \\ \text { pendidikan }\end{array} & \begin{array}{l}\text { kesehatan, } \\ \text { kenerapan }\end{array} \\ & \text { penuli }\end{array}$
mengevaluasi kembali mengenai $\mathrm{Tb}$ paru, diet TKTP dan batuk efektif yang sudah dijelaskan sebelumnya, pasien mampu mengingat dan menjelaskan kembali apa yang sudah dijelaskan oleh penulis. Pukul 10.18 WIB mengukur TTV pasien, TD: 116/84 mmHg, N: 92 x/ menit, RR: $19 \mathrm{x} /$ menit, $\mathrm{S}: 37^{\circ} \mathrm{C}$; pukul 10.30 WIB mengevaluasi pasien tentang tata cara batuk efektif, pasien mengatakan paham, pasien mampu mengulangi cara batuk efektif dengan $2 \mathrm{x}$ napas dalam, lalu $1 \mathrm{x}$ napas dalam tahan dan batukan, dahak dapat keluar 1/4 sendok teh dengan berwarna kehijauan, pasien mampu mengulangi etika batuk mengunakan masker, tissue dan lengan atas; pukul 11.00 WIB menjelaskan aturan minum OAT, efek OAT, PMO dan TB MDR, pasien mengatakan paham dan mampu mengulangi kembali penjelasan OAT yaitu tidak boleh telat walaupun sehari akan mengulang kembali dari awal pengobatan, dengan jangka waktu telat maksimal 30 menit hingga 60 menit dari jam awal minum obat. Pasien mampu menjelaskan PMO bukan hanya untuk mengingatkan pasien dalam meminum OAT namun juga mengawasi hingga tertelannya obat. Pasien mengatakan paham juga mual itu adalah salat satu efek dari salah satu OAT, pasien mengatakan tidak akan telat minum obat karena takut terkena TB MDR yang lebih banyak OAT dan lama waktu peminumannya. Pasien tampak paham dan mampu mengulangi kembali penjelasan perawat; pukul 12.30 WIB mengevaluasi kembali makanan apa saja yang mengandung tinggi protein dan baik dikonsumsi dirumah, pasien mengatakan semua makanan yang mengandung tinggi protein boleh dimakan dan tidak ada pantangan dalam mengkonsumsi apapun.

Pada tanggal 1 Juli 2018. Penulis mengevaluasi kembali mengenai batuk efektif, pengobatan TB paru, prinsip pengobatan, OAT, penjelasan TB MDR dan tugas seorang PMO, pasien mampu mengingat dan menjelaskan kembali apa yang sudah dijelaskan oleh penulis. Pada pelaksanaan ini dilakukan di rumah pasien di Jl. Jati Padang rt12/02 Kel. Jati Padang, Kec. Pasar Minggu, Jakarta Selatan, dikarenakan jadwal pulang yang sudah di jadwalkan oleh dokter yang mengelola pasien yaitu pulang pada tanggal 30 Juni 2018, sedangkan penulis belum melakukan evaluasi pada hari ketiga, sehingga penulis berinisiatif untuk mengunjungi rumah pasien tersebut. Pukul 10.18 WIB mengukur TTV pasien, TD: 131/84 mmHg, N: 95x/ menit, RR: 20x/menit, S: $36,9^{\circ} \mathrm{C}$; pukul 15.25 WIB mengevaluasi pasien tentang batuk efektif, pasien mengatakan semalam dahak keluar setelah 3 kali batuk efektif, dengan warna kehijauan 
dan banyaknya $1 / 2$ sendok teh, pasien mampu mendemosntrasikan batuk efektif dengan 2x napas dalam lalu $1 \mathrm{x}$ napas dalam kemudian tahan dan batukkan, pasien mampu mendemosntrasikan etika batuk mengunakan tissue dan lengan atas; pukul 16.10 WIB mengevaluasi mengenai nutrisi TKTP, pasien mengatakan sudah paham, dan hari ini sudah makan putih telur 5 butir lalu kemarin 4 butir, pasien tampak sedang memakan putih telur; pukul 16.40 WIB mengevaluasi tata cara minum OAT, PMO dan perawatan TB paru, pasien tampak mengerti dan mengatakan minum obat $1 \mathrm{x} /$ hari pada jam 07.00 sebelum makan. Ibu dan suami selalu mengingatkan pasien untuk minum OAT, pasien mengatakan tadi pagi sudah berjemur dan akan membuka jendela rumahnya agar sinar matahari dapat masuk, pasien enggan untuk telat minum OAT karena takut terkena TB MDR, yang merupakan TB yang kebal OAT.

Evaluasi keperawatan pada Tanggal 1 Juli 2018 pukul 16.45 WIB. Subjektif: pasien mengatakan semalam dahak keluar setelah 3 kali batuk efektif, dengan warna kehijauan dan banyaknya $1 / 2$ sendok teh, pasien mengatakan sudah paham, dan hari ini sudah makan putih telur 5 butir lalu kemarin 4 butir, mengatakan minum obat $1 \mathrm{x} /$ hari pada jam 07.00 sebelum makan. Ibu dan suami selalu mengingatkan pasien untuk minum OAT, pasien mengatakan tadi pagi sudah berjemur dan akan membuka jendela rumahnya agar sinar matahari dapat masuk, pasien enggan untuk telat minum OAT karena takut terkena TB MDR, yang merupakan TB yang kebal OAT. Objektif: Pasien tampak sudah paham dan mampu mengulangi beberapa penjelasan perawat, TD: $131 / 84 \mathrm{mmHg}$, $\mathrm{N}$ : 95x/ menit, RR: 20x/menit, S: 36, $9^{\circ} \mathrm{C}$.

\section{Pembahasan \\ Pengkajian}

Penulis menemukan faktor pencetus tuberkulosis paru pada pada $\mathrm{Ny}$.
$\mathrm{Cu}$ adalah kondisi rumah, kepadatan hunian, lingkungan perumahan, serta lingkungan dan sanitasi tempat bekerja yang buruk, seperti ventilasi yang kurang. Di samping itu, kurangnya ventilasi akan menyebabkan kelembaban udara di dalam ruangan naik karena terjadinya proses penguapan cairan dan kulit dan penyerapan, serta terdapatnya barang-barang hasil suami pasien $\mathrm{Ny} . \mathrm{Cu}$ memulung dikumpulkan di samping rumah pasien. Kelembaban ini akan menjadi media yang baik untuk pertumbuhan bakteri-bakteri patogen/bakteri penyebab penyakit, misalnya kuman TB. Sedangkan pada Ny. Ch mengatakan ayah pasien mempunyai riwayat penyakit tuberkulosis dan sembuh, sempat menjalani pengobatan 6 bulan pada 8 tahun lalu.

Menurut Suryo (2010), salah satu faktor resiko yang menyebabkan penyakit TB paru adalah faktor lingkungan sangat erat kaitannya dengan kondisi rumah, kepadatan hunian, lingkungan perumahan, serta lingkungan dan sanitasi tempat bekerja yang buruk. Kondisi rumah dapat menjadi salah satu faktor resiko penularan penyakit TB. Atap, dinding dan lantai dapat menjadi tempat perkembang biakan kuman. Lantai dan dinding yang sulit dibersihkan akan menyebabkan penumpukan debu sehingga akan dijadikan sebagai media yang baik bagi berkembang biaknya kuman mycobacterium tuberculosis. Ventilasi mempunyai fungsi untuk menjaga aliran dalam rumah tersebut tetap segar, hal ini berarti keseimbangan oksigen yang diperlukan oleh penghuni rumah tersebut tetap terjaga. Kurangnya ventilasi akan menyebabkan kurangnya oksigen di dalam rumah. Di samping itu, kurangnya ventilasi akan menyebabkan kelembaban udara di dalam ruangan naik karena terjadinya proses penguapan cairan dan kulit dan penyerapan. Kelembaban ini akan menjadi media yang baik untuk pertumbuhan bakteri- 
bakteri patogen/bakteri penyebab penyakit, misalnya kuman TB.

Berdasarkan klasifikasi pada tabel bisa disimpulkan perbedaan klasifikasi penyakit TB paru, yaitu pada kasus 1 merupakan pasien TB paru dengan putus obat/post primer dan pada pasien kasus 2 merupakan TB paru baru/primer.

Menurut Amin (2010), penyakit tuberkulosis dari sistem lama diketahui pembagian secara patologis; tuberkulosis primer (childhood tuberculosis), tuberkulosis post-primer (adult tuberculosis).

Menurut Price (2008), di Indonesia klasifikasi yang banyak dipakai adalah berdasarkan kelainan klinis, radiologis, dan mikrobiologis: Tuberkulosis paru baru, bekas tuberkulosis paru, tuberkulosis paru tersangka, yang terbagi dalam: tuberkulosis paru tersangka yang diobati, di sini sputum BTA negatif, tetapi tandatanda lain positif. Tuberkulosis paru tersangka yang tidak diobati, di sini sputum BTA negatif dan tanda-tanda lainnya meragukan.

\section{Manifestasi Klinik}

Kasus 1 Ny. Cu. Pasien mengatakan: Tenggorokan gatal, batuk terus menerus, terdapat dahak tetapi sering tidak dapat dikeluarkan, dahak berwarna putih kekuningan, pasien mengatakan putus OAT sejak Desember tahun 2017 lalu, demam pada pagi dan malam hari, sering haus saat demam, keringat dingin, penurunan berat badan hingga $27 \mathrm{~kg}$ dalam setahun dari $75 \mathrm{~kg}$ hingga $48 \mathrm{~kg}$, tinggi badan $153 \mathrm{~cm}$, LILA $18 \mathrm{~cm}$, IMT 20,52 konjungtiva pasien anemis, mukosa bibi kering, postur tubuh kurus, nafsu makan baik, makan tiga kali sehari, makan habis satu porsi, pasien terlihat lemas, membran mukosa kering, turgor kulit elastis dan sesak namun sudah sedikit berkurang.

Kasus 2 Ny. Ch, Pasien mengatakan: Batuk terus menerus hingga pasien merasa lelah, batuk sudah 1 bulan, sekret berwarna hijau, demam pada pagi dan menjelang sore hari, keringat pada malam hari, riwayat anemia gravis 2 tahun lalu dan sudah 6,5 tahun menderita diabetes melitus, Berat badan pasien sebelum sakit $54 \mathrm{~kg}$ dan berat badan sekarang $45 \mathrm{~kg}$, terjadi penurunan berat badan $10 \mathrm{~kg}$ dalam kurun waktu satu bulan, tinggi badan $156 \mathrm{~cm}$, Lila $22 \mathrm{~cm}$, IMT 16, 52, konjungtiva pasien anemis, mukosa bibir kering, postur tubuh kurus, nafsu makan menurun, mual, makan tiga kali sehari, makan habis satu porsi dan harus dipaksa, lemas.

Berdasarkan uraian diatas dapat disimpulkan tanda gejala yang dialami oleh kedua kasus hampir serupa dan sesuai dengan teori, ditandai adanya batuk yang terjadi terus-menerus yang disertai dengan demam pada pagi atau menjelang malam, penurunan berat badan dalam kurun waktu dekat.

Satu tanda gejala yang tidak ditemukan pada kedua kasus namun ada di teori adalah nyeri dada. Nyeri dada timbul apabila infiltrasi radang yang sudah sampai ke pleura sehingga menimbulkan pleuritis. Kuman akan berkoloni di tempat yang kaya oksigen dan menginfeksi pleura sehingga terjadi gesekan kedua pleura sewaktu pasien menarik atau melepaskan napasnya.

\section{Komplikasi}

Kasus $1 \mathrm{Ny} . \mathrm{Cu}$, Kesan Hasil foto thorak tanggal 12 Juni 2018 Infiltrat di kedua paru dan konsolidasi di lapangan tengah paru kiri Ec. Tb paru. susp. Efusi Pleura. Kasus $2 \mathrm{Ny}$. Ch, Kesan Hasil foto thorak tanggal 22 Juni 2018 Infiltrat di kedua paru terutama di lapangan kanan bawah, DD/ TB paru, Pneumonia.

Pada kasus 1 di dapatkan bahwa pasien sudah mengalami komplikasi dengan hasil rontgen suspek efusi pleura, sedangkan pada kasus 2 belum ditemukan adanya komplikasi lainnya. Efusi pleura merupakan komplikasi pada TB paru, apabila terdapat proses TB di bagian paru yang dekat sekali dengan pleura, pleura akan ikut meradang dan menghasilkan cairan eksudat. Dengan kata lain terjadilah pleuritis eksudatif. Tidak jarang proses TB nya masih begitu 
kecil, sehingga pada foto paru belum tampak kelainan. Bilamana cairan eksudat masih sedikit (tinggi cairan tidak melebihi $25 \%$ tinggi paru), cukup diberikan terapi spesifik saja, tetapi bila cairan semakin banyak, perlu dilakukan fungsi dan cairan eksudat dikeluarkan sebanyak mungkin, untuk menghindari terjadinya di kemudian hari.

\section{Pemerikasaan Penunjang}

Pada kedua kasus dilakukan sesuai dengan teori, namun pada kedua kasus juga tidak dilakukan satu pemeriksaan penunjang yang ada di teori tidak dilakukan pada kasus yaitu tes tuberkulin. Pemeriksaan ini masih banyak dipakai untuk membantu menegakkan diagnosis tuberkulosis terutama pada anak-anak (balita). Biasanya dipakai tes mantoux yakni dengan menyuntikkan $0,1 \mathrm{cc}$ intrakutan. Setelah 48-72 jam tuberkulin disuntikkan akan timbul reaksi berupa indurasi kemerahan. Berdasarkan hal-hal tersebut, hasil test mantoux dibagi dalam: Indurasi 0-5 mm (diameternya): mantoux negatif : golongan no sensitive. Di sini peran antibodi paling menonjol. Indurasi 6-9 $\mathrm{mm}$ : hasil meragukkan = golongan low grade sensitivity. Indurasi $10-15 \mathrm{~mm}$ : mantoux positif = golongan normal sensitivity. Di sini peran antibodi seimbang. Indurasi lebih dari $15 \mathrm{~mm}$ manoux positife kuat $=$ golongan hipersensitivity. Di sini peran atibodi seluler paling menonjol.

\section{Penatalaksanaan Medis}

Penatalaksanaan medis pada kasus 1 dan 2 sama-sama diberikan OAT dengan dosis yang berbeda, namun pada kasus 2 diberikan terapi obat diabetes melitus seperti metformin $3 \times 500 \mathrm{mg}$ (pukul 07.00, 12.00, 18.00 WIB), levemir $1 \mathrm{x} 8$ unit (pukul 22.00 WIB), tetapi tidak diberikan pada kasus 1 , walaupun pasien pada kasus 1 sama-sama memiliki penyakit DM, ini dikarenakan pasien pada kasus 1 gula darahnya dapat terkontrol tanpa menggunakan insulin, sedangkan pada kasus 2 gula darah pasien terkontrol hanya dengan terapi insulin (levemir).

Penatalaksanaan medis yang ada pada teori tetapi tidak ada pada kasus yaitu pemberian obat streptomisin karena pada pasien 2 baru pertama kali menderita TB paru, dan pada kasus 1 tidak diberikan streptomicin karena pasien merupakan TB dengan putus OAT obat streptomicin diberikan pada pasien yang sudah pernah menderita TB paru dan kambuh kembali.

Kemudian penatalaksanaan medis yang sesuai teori dan ada di kasus, yaitu pada kedua kasus diatas juga masingmasing diberikan omeprazole dengan alasan mengurangi rasa mual karena efek samping dari dua jenis OAT, yaitu rifampisin dan pirazinamid. Pada kasus 1 diberikan curcuma 3 x 1 tab (pukul 07.00, 12.00, \& 18.00 WIB) membantu pasien dalam menambah nafsu makan karena berat badan yang menurun drastis dalam 1 tahun $27 \mathrm{~kg}$.

Penatalaksanaan yang ada dikasus namun tidak ada di teori yaitu, pasien kasus 1 juga mendapat terapi $\mathrm{NaCl} 0,9 \%$ per 12 jam 14 tetes/menit, $\mathrm{NaCl} 3 \%$ per 24 jam 7 tetes/menit yang berguna untuk memperbaiki nilai elektrolit yang masih dalam keadaan fluktuasi. Sedangkan pada kasus 2 pasien mendapat terapi $\mathrm{NaCl}$ $0.9 \%$ untuk maintenance cairan pemberian intravena.

\section{Diagnosa}

\section{Keperawatan Resiko Penyebaran Infeksi}

Berdasarkan

pembahasan diagnosa keperawatan resiko penyebaran infeksi, pada tabel 4. 11 pada kedua kasus sama-sama ditemukan adanya demam yang terjadi pada malam hari, pagi hari atau menjelang sore. Terdapatnya batuk produktif yang terjadi 1 bulan atau lebih. Penurunan berat badan secara drastis, meningkatnya hasil laboratorium LED diatas normal.

Menurut Sudoyo (2010), demam merupakan gejala pertama dari tuberkulosis paru, biasanya subfebril menyerupai demam influenza yang 
segera mereda. Tetapi kadang-kadang dapat mencapai suhu tinggi yaitu 40-41 ${ }^{\circ} \mathrm{C}$. Serangan demam pertama dapat sembuh sebentar, tetapi kemudian dapat timbul kembali. Begitulah seterusnya sehingga pasien merasa tidak pernah terbebas dari serangan demam influenza. Keadaan ini tergantung dari daya tahan tubuh dan berat ringannya infeksi kuman tuberkulosis yang masuk.

Menurut Sudoyo (2010), pada saat tuberkulosis baru dimulai akan didapat jumlah leukosit yang sedikit meninggi dengan hitung jenis pergeseran ke kiri. Jumlah limfosit masih dibawah normal, LED mulai meningkat. Bila penyakit mulai sembuh jumlah leukosit kembali normal dan jumlah limfosit masih tinggi. LED mulai menuju kearah normal.

\section{Perencanaan Keperawatan}

Pada diagnosa resiko penyebaran infeksi berhubungan dengan pertahanan sekunder tidak adekuat, diperlukan perencanaan penerapan pendidikan kesehatan etika batuk/tata cara batuk efektif, diet TKTP serta perawatan TB paru yang meliputi penjelasan TB paru, kepatuhan meminum OAT, akibat lanjut seperti TB MDR, agar mengurangi terjadi masalah kekambuhan atau putus obat pada pasien TB paru yang dapat mengakibatkan resistensi mycobacterium tuberkulosis terhadap obat anti TB. Pengetahuan tentang penyakit TB Paru merupakan hal yang sangat penting agar tidak menimbulkan peningkatan jumlah kasus TB Paru akibat penularan dari pasien kepada orang lain, sehingga perlunya seseorang mendapatkan informasi tentang TB dan pencegahannya.

\section{Pelaksanaan Keperawatan}

Pelaksanaan resiko penyebaran infeksi berhubungan dengan pertahanan sekunder tidak adekuat, pada kedua kasus sudah dapat dilakukan pendidikan kesehatan etika batuk/batuk efektif, diet TKTP, dan perawatan TB paru. Pada saat pendidikan kesehatan dilakukan, pada kasus 1 tidak ada hambatan. Penerapan pendidikan kesehatan pada hari pertama dan kedua dilakukan pada pasien yang ditemani oleh suami, dan pada hari ketiga pasien ditemani oleh anak laki-laki pertamanya. Pasien dan keluarga tampak kooperatif dan mendengarkan dengan baik saat berlangsungnya pendidikan kesehatan.

Pada kasus 2 pendidikan kesehatan dilakukan pada pasien yang di temani oleh ibunya, pasien tampak kooperatif dan mampu menyimak pendidikan kesehatan dengan baik, namun pada kasus 2 ini memiliki hambatan pada tanggal 30 Juni 2018, dimana Ny. Ch sudah diperbolehkan pulang saat penulis sedang mengelola $\mathrm{Ny}$. Ch di hari kedua, sehingga solusinya penulis mengunjungi kerumah pasien untuk mengevaluasi pelaksanaan di hari ketiga serta melengkapi hasil penelitian, sehingga pada kasus 1 dan 2 memiliki jumlah kelolaan yang sama, yaitu 3 hari.

Menurut Nursalam (2012), pendidikan kesehatan adalah proses yang direncanakan dengan sadar untuk menciptakan peluang bagi individuindividu untuk senantiasa belajar memperbaiki kesadaran (literacy) serta meningkatkan pengetahuan dan keterampilan (skills) demi kepentingan kesehatannya.

\section{Evaluasi Keperawatan}

Evaluasi adalah tahapan akhir dari proses keperawatan. Evaluasi berisikan nilai informasi mengenai pengaruh perencanaan yang telah direncanakan dan merupakan perbandingan dari hasil yang diamati sesuai kriteria hasil yang telah dibuat pada tahap perencanaan. Dalam melakukan evaluasi ini penulis hanya memfokuskan evaluasi hasil dari pelaksanaan keperawatan mengenai penerapan pendidikan kesehatan etika batuk/batuk efektif, diet TKTP, dan perawatan TB paru yang meliputi penjelasan TB paru, kepatuhan meminum OAT, akibat lanjut seperti TB MDR yang terkait dengan diagnosa resiko penyebaran infeksi. 
Evaluasi dilaksanakan perhari setelah dilakukannya pelaksanaan keperawatan penerapan pendidikan kesehatan sesuai dengan kedua kasus yaitu pada kasus $1 \mathrm{Ny}$. $\mathrm{Cu}$ tanggal 26 Juni 2018 hingga tanggal 28 Juni 2018 dan pada kasus 2 Ny. Ch tanggal 29 Juni 2018 hingga 1 Juli 2018 penulis menerapkan pendidikan kesehatan yang berfokus kepada tindakan etika batuk/batuk efektif, diet TKTP, dan perawatan TB paru meliputi penjelasan TB paru, kepatuhan meminum OAT, akibat lanjut seperti TB MDR.

Evaluasi diagnosa resiko tinggi penyebaran infeksi terutama pada pelaksanaan penerapan pendidikan kesehatan batuk efektif, diet TKTP, perawatan TB paru yang meliputi penjelasan TB paru, kepatuhan meminum OAT, akibat lanjut seperti TB MDR. Evaluasi yang dihasilkan pada kedua kasus tersebut setelah dilakukan tindakan keperawatan selama 3x24 jam, penulis mengevaluasi pelaksanaan penerapan pendidikan kesehatan pada pasien tuberkulosis, ditandai dengan pemahaman pasien dalam penjelasan perawat, pasien mampu mengulangi penjelasan diet TKTP, perawatan TB paru meliputi penjelasan TB paru, kepatuhan minum OAT serta akibat lanjut seperti TB MDR yang sudah dijelaskan perawat, dan mampu mendemonstrasikan etika batuk dan cara batuk dengan benar.

Berdasarkan penelitian Utari, (2014), yang berjudul efektifitas pendidikan kesehatan terhadap peningkatan pengetahuan keluarga tentang infeksi saluran pernapasan akut (ISPA). Penelitian ini menggunakan desain penelitian quasi experiment with control group. Metode penelitian digunakan yaitu pre-test and 3 post-test non-equivalen control group. Penelitian dilakukan di Kelurahan Rejosari wilayah kerja Puskemas Rejosari Pekanbaru pada bulan januari 2014. Hasil penelitian yang telah dilakukan, pada analisa dua sampel tidak berhubungan (independen), peneliti menggunakan uji Maan-Whitney didapatkan hasil probabilitas $0,000<\alpha$ 0,05 . Maka Ho ditolak, yang berarti pengetahuan keluarga yang mendapat pendidikan kesehatan benar-benar berbeda dengan pengetahuan keluarga yang tidak mendapatkan pendidikan kesehatan. Kesimpulannya ada perbedaan pengetahuan sebelum dan setelah diberikan pendidikan kesehatan menggunakan media audiovisual terhadap peningakatan pengetahuan keluarga.

\section{Kesimpulan}

Faktor pencetus TB paru pada $\mathrm{Ny}$. $\mathrm{Cu}$ karena terdapat barang bekas di dekat rumahnya yang merupakan pekerjaan suaminya yaitu sebagai pemulung. Sedangkan pada Ny. Ch karena ayah pasien yang memiliki riwayat TB paru 8 tahun lalu. Selain itu keluarga mengatakan mereka tinggal di pemukiman yang padat penduduk, dengan ventilasi yang kurang di rumah pasien.

Pada tahap pelaksanaan keperawatan, penulis sudah melaksanakan sesuai dengan intervensi. Pada penelitian ini penulis hanya fokus membahas pelaksanaan penerapan pendidikan kesehatan perawatan TB paru, dengan hasil evaluasi keperawatan pada pelaksanaan penerapan pendidikan kesehatan perawatan TB paru, ditandai dengan pemahaman pasien ditandai dengan pasien dapat menjelaskan kembali pengertian TB Paru, etiologi, tanda dan gejala, dan pasien dapat menjelaskan kembali diet TKTP, perawatan TB paru meliputi penjelasan TB paru, kepatuhan meminum OAT serta akibat lanjut seperti TB MDR yang sudah dijelaskan perawat, dan mampu mendemonstrasikan etika batuk dan cara batuk dengan benar.

\section{Saran}

1. Diharapkan dapat mempertahankan kinerja dan kualitas dalam proses keperawatan pada pasien yang 
mengalami TB paru dengan tetap menerapkan pendidikan kesehatan dan pemberian leaflet kepada pasien dan keluarga, agar tidak terjadinya peristiwa putus obat atau relaps karena ketidakpatuhan dalam meminum OAT.

2. Perawat dapat menerapkan pemakaian masker pada petugas kesehatan lainnya terutama saat memasuki ruang isolasi paru.

3. Lebih menegaskan pada keluarga pasien yang datang menjenguk dalam penggunaan masker saat memasuki ruang isolasi, dan lebih menjelaskan alasan menggunaan masker tersebut diruangan isolasi.

4. Lebih memberikan pengertian pada pasien dan keluarga dalam penggunaan masker di ruangan, keadaan pintu kamar yang harus selalu tertutup, dan memberikan discharge planning pemakaian masker dirumah atau lingkungan keluarga

\section{Daftar Pustaka}

[1] Alie. Y., \& Rodiyah. (2013). Pengaruh batuk efektif terhadap pengeluaran sputum pada pasien tuberkulosis di Puskesmas Peterongan Kabupaten Jombang. Skripsi. Stikes Pemkab. Diunduh dari

http://www.stikespemkabjombang.a c.id/

[2] Aryani, R., dkk. (2009). Prosedur klinik keperawatan pada mata ajar kebutuhan dasar manusia. Jakarta: Trans Info Media.

[3] Asih, N., \& Effendy, C. (2008). Keperawatan medikal bedah: Klien dengan gangguan sistem pernapasan. Jakarta: EGC.

[4] Asmadi. (2008). Teknik prosedural keperawatan konsep dan aplikasi kebutuhan dasar manusia. Jakarta: Salemba Medika.

[5] Danusantoso, H. (2013). Buku saku ilmu penyakit paru. Ed.2. Jakarta: EGC.
[6] Doenges, M., Moorhouse, M., \& Geissler, A. (2012). Rencana asuhan keperawatan: Pedoman untuk perencanaan dan pendokumentasian perawatan pasien. Ed.3. Jakarta: EGC.

[7] Effendi, F., \& Makhfudli. (2009). Keperawatan kesehatan komunitas teori dan praktik dalam keperawatan. Jakarta: Salemba Medika.

[8] Lusianah, dkk. (2012). Prosedur keperawatan. Jakarta: Trans Info Media.

[9] Manurung, S., Suratun., Krisanty, P., \& Ekarini, N. (2013). Asuhan keperawatan gangguan sistem pernapasan akibat infeksi. Jakarta: Trans Info Media.

[10] Mardiono, S. (2013). Pengaruh latihan batuk efektif terhadap frekuensi pernafasan pasien TB paru di Instalasi Rawat Inap penyakit dalam rumah sakit Pelabuhan Palembang tahun 2013. Jurnal Harapan Bangsa, 1(2), 224-227. Diunduh dari http://scholar.google.go.id/scholar.

[11] Mboi, N. (2013). Riset kesehatan dasar (RISKESDAS) 2013. Jakarta: Kemenkes RI.

[12] Nurhayati, I., Kuriawan, T., \& Mardiah, W. (2015). Perilaku pencegahan penularan dan faktorfaktor yang melatarbelakanginya pada pasien tuberkulosis multidrugs resisten. Skripsi. Universitas Padjajaran. Diunduh dari http://jkp.fkep.unpad.ac.id/article

[13] Nurarif, A., \& Kusuma, H. (2013). Aplikasi asuhan dasar keperawatan berdasarkan diagnosa medis. Jilid 2. Jogjakarta: Medi Action.

[14] Nursalam., \& Ferry E. (2012). Pendidikan dalam keperawatan. Jakarta: Salemba Medika.

[15] Potter, P., \& Perry, A. (2014). Fundamentals of nursing. Canada: Elsevier.

[16] Price, S., \& Wilson, L. (2008). Patofisiologi konsep klinis dan 
proses-proses penyakit. Jakarta: EGC.

[17] Sediaoetama, A. (2010). Ilmu gizi untuk mahasiswa dan profesi. Jakarta: Dian Rakyat.

[18] Sudoyo, A., Setyohadi, B., Alwi, I., Simadibrata, M., \& Setiati, S. (2010). Buku ajar ilmu penyakit dalam. Ed.5. Jilid 2. Jakarta: Internal Publishing.

[19] Suryo, Joko. (2010). Gangguan sistem pernapasan. Yogyakarta: B First.

[20] Sutarjo, U. (2014). Pedoman nasional pengendalian tuberkulosis. Jakarta: Kementrian Kesehatan RI.

[21] Syaifuddin. (2011). Anatomi fisiologi: Kurikulum berbasis kompetensi untuk keperawatan dan kebidanan. Jakarta: EGC.

[22] Tirtana, B. (2011). Faktor-faktor yang mempengaruhi keberhasilan pengobatan pada pasien tuberkulosis paru dengan resistensi obat tuberkulosis di wilayah Jawa Tengah. Skripsi. Universitas
Diponegoro. Diunduh dari http://eprints.undip.ac.id/

[23]Utari, Weni., Arneliwati, \& Riri Novayelinda. (2014). Efektifitas pendidikan kesehatan terhadap peningkatan pengetahuan keluarga tentang infeksi saluran pernapasan akut (ISPA). Tesis. Universitas Riau. Diunduh dari http://scholar.google.go.id/scholar

[24] Ummami, Y. (2016). Pengaruh pendidikan kesehatan tentang tuberkulosis terhadap peningkatan pengetahuan dan sikap penderita dalam pencegahan penularan tuberkulosis di Puskesmas Simo. Skripsi. Universitas Muhammadiyah Surakarta. Diunduh dari http://eprints.ums.ac.id/

[25] Wahyuliana. (2013). Diet tinggi kalori dan protein. Jurnal nutrisi pasien tuberkulosis paru. 2(1), 24 59. Diunduh dari http://www.google.co.id/dietTKTP.

[26] Ward, J., Leach, R., \& Wiener, C. (2007). At a glance sistem respirasi. Ed.2. Jakarta: EGC 